\title{
Efforts to improve learning outcomes of Indonesian language through participatory method in SMP Negeri 266 Jakarta
}

\author{
Nurhayati \\ SMP Negeri 266 Jakarta \\ J1. Cilincing Bakti VI No.29, RT.4/RW.9, Cilincing, Kota Jkt Utara, Daerah Khusus Ibukota Jakarta 14120; \\ Indonesia; e-mail: enhaye18@yahoo.co.id
}

\begin{abstract}
This research was being done in Grade VII-A SMP 266 Jakarta with total students is 36 , it was conducted on January - June 2015. The method used in this Action Research by Stephen Kemmis and Robin McTaggart model. It consists of two cycles and each cyclehasthree meetings, and every meeting has four components; Planning, Action Research, Observation and Reflection. The instrument is a questionnaire. In The first cycle, the students made a group in random,the teacher gave assignment in writing a poem. The result was; some student still talked to each other. Yet, on the next cycle the students had to present their job so that they are more interested and tried to finish the job with their group seriously. The average score in the first cycle is 72.61 and the second cycle is improving to 82.86. The result of the observation shows that the learning method with cooperative Participatory method can improve the students learning outcomes
\end{abstract}

Keywords: Cooperative participatory method, Students 'learning outcomes, Bahasa Indonesia.

\begin{abstract}
Article History: Received: 09/03/2017; Revised: 21/04/2017; Accepted: 01/05/2017; Published: 05/05/2017
How to Cite (MLA $7^{\text {th }}$ ): Nurhayati. "Efforts to improve learning outcomes of Indonesian language through participatory method in SMP Negeri 266 Jakarta." Hortatori: Jurnal Pendidikan Bahasa dan Sastra Indonesia 1.1 (2017): 1520. Print/Online. Copyrights Holder: Nurhayati. First Publication: Hortatori Jurnal Pendidikan Bahasa dan Sastra Indonesia (2017).
\end{abstract}

\section{Pendahuluan}

Salah satu keterampilan dalam pelajaran bahasa Indonesia adalah keterampilan menulis ,selain keterampilan mendengar, membaca, dan berbicara. Keempat keterampilan tersebut mempunyai keterkaitan dan ketepaduan yang sangat erat.

Menulis merupakan keterampilan dasar yang dapat menunjang keberhasilan peserta didik di semua jenjang sekolah, sebab kegiatan belajar mengajar pada semua materi pelajaran diperlukan keterampilan menulis. Peningkatan kemampuan peserta didik dalam menulis tidak dapat lepas dari keterampilan berbahasa. Pelajaran bahasa Indonesia, khususnya menulis masih kurang diminati peserta didik, terlebih dengan menulis puisi. Bahkan keterampilan menulis dalam pelajaran bahasa Indonesia di SMP masih dianggap sulit oleh peserta didik.

Suatu fakta bahwa,keterampilan menulis dalam pelajaran bahasa Indonesia masih dianggap sulit oleh peserta didik . Hal ini terlihat pada rendahnya nilai menulis pada saat ujian praktik .Peserta didik yang mendapat nilai KKM hanya mencapai 27, $77 \%$ saja. Kemampuan menulis secara intensif terhambat oleh ketidakmampuan peserta didik untuk dapat berpikir, berkreasi, dan berkomonikasi dengan bahasa Indonesia secara lugas, langsung, dan lancar. Guru kadang-kadang menekankan teori dan pengetahuan daripada keterampilan berbahasa. Proses belajar mengajar sering didominasi guru dari pada berpusat padapeserta didik. 
Interaksi yang aktif antara guru dan peserta didik dapat mengurangi dominasi guru dalam proses pembelajaran dan dapat meningkatkan motivasi peserta didik.Untuk mencapai tujuan belajar bahasa Indonesia, peserta didik harus mempunyai motivasi belajar bahasa Indonesia. SMPN 266 Jakarta salah satu lembaga formal juga memiliki permasalahan dalam proses pembelajaran bahasa Indonesia khususnya keterampilan menulis karena kurang maksimalnya proses pembelajaran Bahasa Indonesia.

Banyak hal yang harus diperhatikan oleh seorang guru bahasa Indonesia agar kemampuan menulis peserta didik dapat lebih signifikan. Pertama kali guru harus menentukan pendekatan dan metode yang sesuai dengan tujuan pembelajarannya. Kedua seorang guru harus mampu membuat peserta didik untuk aktif terlibat dalam proses pembelajaran sehingga proses belajar mengajar tidak hanya berpusat pada guru.

Dari uraian tersebut tampak bahwa permasalahannya adalah minat belajar peserta didik rendah sehingga berdampak pada hasil belajarnya yang rendah. Sebagai akar masalahnya adalah guru masih konvensional yaitu guru mendominasi dan menjadi satu-satunya sumber belajar. Di samping itu guru tidak menggunakan media yang menarik sehingga membuat peserta didik bosan.

Oleh karena itu, penulis akan berusaha melakukan perubahan dalam proses pembelajaran dengan menggunakan berbagai metode pembelajaran di kelas dengan tujuan untuk meningkatkan minat dan kemampuan peserta didik dalam menulis puisi. Kemampuan pendidik dalam proses pembelajaran sangat berpengaruh pada pencapaian peserta didik yang berkualitas. penulis akan melakukan pembelajaran menggunakan model pembelajaran kooperatif. Hal ini karena pembelajaran kooperatif membuat interaksi antar peserta didik menjadi efektif dan mereka saling membantu. Pendidik di sekolah cukup memegang peranan penting untuk membentuk peserta didik berkualitas dan terampil dalam menulis. Karena itu perlu adanya peningkatan mutu pembelajaran Bahasa Indonesia di sekolah khususnya.

Masalah lain yang dihadapi peserta didik adalah pendekatan pembelajaran yang belum sesuai ,sehingga mereka mengalami kesulitan untuk memahami materi pembelajaran yang disampaikan oleh guru

\section{Metode}

Berdasarkan uraian di atas peneliti berusaha untuk menyelesaikan masalah tersebut. Oleh karena itu peneliti akan menggunakan "Metode Kooperatif Parsipatori" dalam kegiatan belajar mengajar untuk laporan penelitian tindakan kelas,sehingga peneliti mengangkat masalah ini dengan judul" Upaya Meningkatkan Hasil Belajar Bahasa Indonesia Melalui Metode Kooperatif Parsipatori di SMP Negeri 266 Jakarta."

Dalam menerapkan Metode Kooperatif Parsipatif diharapkan peserta didik akan meningkatkan motivasinya dalam mengikuti pembelajaran di kelas, dan juga adanya peningkatan kemampuan dalam penguasaan materi,,dan bertanggung jawab dalam melaksanakantugasnya,dengan demikian hasil belajar dapat meningkat.

Penelitian ini bertujuan untuk menemukan jawaban dari rumusan masalah ,yaitu melalui metode kooperatif Metode Parsipatori dapat meningkatkan keaktifan dan respon peserta didik dalam belajar,serta meningkatkan hasil belajar Bahasa Indonesia khususnya pada Kompetensi Dasar 16.1 Menulis kreatif Puisi berkenaan dengan keindahan alam pada kelas VII-A.

Pendidikan adalah salah satu aspek dalam kehidupan yang terus berubah seiring dengan perkembangan zaman. Seiring dengan kemajuan ilmu pengetahuan dan teknologi, menuntut peserta didik untuk mampu mengubah pandangannya yang berbunyi "mampu bersaing" menjadi "mampu memenangkan persaingan". Sekolah bukanlah pabrik ilmu dengan gaya belajar yang membosankan. Perubahan aktivitas belajar yang mengikuti perubahan zaman harus selalu diikuti perkembangannya dengan menggunakan metode-metode tertentu agar kita tidak tertinggal dari kemajuan ilmu pengetahuan dan teknologi. Makin tepat metode yang digunakan diharapkan makin efektif pula pencapaian tujuan tersebut. Salah satu metode tersebut adalah metode partisipatori.

Britha Mikkelsen (2001) mengatakan bahwa "Metode partisipatori membantu menciptakan pengalaman belajar yang efektif." Kata partisipatori berasal dari kata 'partisipasi' yang berarti suatu proses aktif yang mengandang arti bahwa orang atau kelompok yang terkait mengambil inisiatif dan menggunakan kebebasannya untuk melakukan hal itu." Metode ini digolongkan ke dalam lima kelompok dan diurutkan guna mendapatkan efek kumulatif yaitu (1) metode kreatif, (2) metode investigatif, (3) metode analitis, (4) metode perencanaan, dan (5) metode informatif Dengan demikian, metode partisipatori merupakan alat dalam memajukan ideologi atau tujuan yang normatif. 
Menurut Made Pidarta (1990), "Kata partisipatori berasal dari kata partisipasi, yaitu pelibatan seseorang atau beberapa orang dalam suatu kegiatan." Dapat diketahui bahwa metode partsipatori ini mengharuskan orang-orang terlibat untuk menyelesaikan suatu kegiatan.

Dalam hal menulis puisi, "Metode partisipaiori adalah metode pembelajaran yang lebih menekankan keterlibatan peserta didik secara penuh. Peserta didik dianggap sebagai penentu keberhasilan belajar" (Depdiknas, 2004). Setiap peserta didik adalah unik. Peserta didik mempunyai kelebihan dan kelemahan masing-masing. Oleh karena itu, proses penyeragaman dan penyamarataan akan membunuh keunikan itu. Dalam metode partisipatoris peserta didik aktif, dinamis, dan berlaku sebagai subjek belajar. Hal itu bukan berarti guru harus menjadi pasif, melainkan guru menjadi fasilitator yang aktif dalam memfasilitasi belajar peserta didik. Guru memberikan kesempatan belajar yang tepat kepada peserta didik dan mendorong mereka untuk secara bebas menyampaikan pemikiran dan membahas masalah penting secara konstruktif. Dengan berpartisipasi aktif, peserta didik dapat menemukan hasil belajar yang maksimal.

Ciri-ciri pokok pendidikan partisipatori, yaitu (1) belajar dari realita atau pengalaman, (2) tidak menggurui, dan (3) dialogis. Kemudian, panduan prosesnya disusun dengan sistem daur belajar dari pengalaman yang distrukturkan saat ini (structural experiences learning cycle). Rincian proses tersebut adalah rangkai ulang, ungkapan, kaji urai, kesimpulan, dan tindakan. Dalam pembelajaran menulis puisi, peserta didik melakukan rangkai ulang dari suatu peristiwa yang dialami dalam kehidupan nyata ke dalam bentuk puisi. Peserta didik bebas mengungkapkan pikirannya tanpa harus merasa rendah diri. Setelah itu, guru mengkaji materi tersebut bersama-sama dengan peserta didik, lalu menguraikan unsur intrinsik dan aspek kebahasaan yang terkandung dalam puisi. Kemudian, guru bersama peserta didik membuat kesimpulan dan melakukan tindakan dengan meminta peserta didik menulis puisi.

Pembelajaran aktif dan partisipatori memungkinkan guru menggunakan banyak cara untuk membantu peserta didik belajar. Ketika peserta didik belajar, mereka menggunakan beberapa cara belajar. Beberapa cara belajar peserta didik, yaitu:Verbal atau linguistik (berbicara atau berbahasa). Sebagian peserta didik berpikir dan belajar melalui tulisan dan lisan; memori; dan proses mengingat kembali. Logika atau matematika. Sebagian peserta didik berpikir dan belajar melalui logika dan perhitungan, Mereka dengan mudah dapat menggunakan angka, mengenah pola abstrak, dan melakukan pengukuran yang tepat. Visual atau spasial (penglihatan atau orientasi bagian) sebagian peserta didik menyukai seni seperti menggambar, melukis, atau membuat patung. Mereka mampu membaca peta, grafik, dan diagram dengan mudah. Tubuh atau kinestetik (gerakan otot/lulang). Sebagian peserta didik belajar melalui aklivitas fisik sepcrti melalui permainan atau drama. Musik atau irama. Sebagian peserta didik belajar paling baik melalui bunyi, irama, dan pengulangan. Antarpribadi. Sebagian peserta didik lebih mudah belajar melalui kerja kelompok. Mereka menyenangi kegiatan kelompok, mudah memahami situasi sosial, dan mereka mudah bergaul dengan orang lain.Intrapribadi. Sebagian peserta didik belajar paling baik secara individu dan mandiri. Mereka lebih mudah bekerja sendiri dan lebih memahami kekuatan kelemahan diri. Naturalis. Sebagian peserta didik belajar sendiri melalui lingkungan alam sekitar secara langsung .

\section{Hasil dan Diskusi}

Penelitian tindakan kelas ini dilaksanakan dengan tujuan meningkatkan aktifitas dan prestasi belajar siswa kelas VII-A SMP Negeri 266 Jakarta,dengan kompetensi dasar, Menulis puisi berkenaan dengan keindahan alam dengan metode Parsipatori.

Peneliti memulai proses pembelajaran pada siklus I dengan harapan dapat meningkatkan kemampuan peserta didik dalam menulis puisi berkenaan dengan keindahan alam. SK.16, KD 16.1 KTSP kelas VII ,semester genap. Pada pertemuan pertama siklus I dan pertemuan kedua masih banyak kelemahankelemahannya karena ternyata peserta didik masih ada yang bercanda dengan kelompoknya, ada juga peserta didik yang belum fokus mendengarkan penjelasan guru, sehingga mempengaruhi kesungguhan peserta didik yang lain dalam bertanya pada guru jika ada hal yang belum dipahami mereka. Selain itu proses pembelajaran masih kurang optimal karena peserta didik masih enggan untuk menyampaikan tanggapannya terhadap penjelasan guru maupun hasil pekerjaan temannya.Tidak dapat dipungkiri dari segi guru pun belum menciptakan suasana kelas yang kondusif. Pengelolaan kelas pun belum maksimal.

Hasil penelitian yang dilaksanakan pada siklus I ini masih diperoleh hasil yang masih sangat rendah, dilihat dari hasil posttest secara klasikal pada pertemuan ketiga yaitu seabagai berikut ,dari 36 
peserta didik baru 18 peserta didik atau $50 \%$ yang mendapat nilai tuntas dan sebanyak 18 peserta didik atau 50\% yang belum mendapat nilai tidak tuntas, yaitu di bawah nilai KKM yaitu nilai 75 . Nilai tertinggi pada siklus I adalah 90, sedangkan nilai terendah adalah 65 dari skor sempurna menulis puisi, yaitu 100.

Beberapa kekurangan yang masih terdapat pada siklus pertama, maka peneliti mengambil langkah-langkah perbaikan yang dilakukan dalam kegiatan pembelajaran, selanjutnya yaitu pada proses pembelajaran siklus II, antara lain guru harus harus tegas kepada peserta didik bahawa mereka harus fokus dan sungguh-sungguh dalam menyimak penjelasan guru maupun dalam berdiskusi mereka harus saling menghargai dalam menanggapi pendapat kelompoknya ataupun dari kelompok lain.Selain itu mereka diharuskan bertanggung jawab mempresentasikan hasil karya dari kelompoknya masing-masing sebelum dikumpulkan sebagai hasil forto folio mereka dan selnjutnya menyelesaikan tugas perorangan juga harus dikumpulkan sebagai hasil nilai perorangan. Setelah guru mengadakan perbaikan seperti disebutkan di atas, maka terjadi peningkatan dan keaktifan peserta didik, serta tercipta kesungguhan dalam belajar sehingga dapat meningkatkan nilai evaluasi hasil belajar peserta didik yang dibuktikan dari nilai yang berbeda secara signifikan yaitu, Secara rinci dijelaskan bahwa hanya 4 orang peserta didik atau $11,11 \%$ dari 36 peserta didik mendapatkan skor nilai yang tidak tuntas yaitu belum mencapai nilai yang merupakan batas nilai yang telah ditetapkan nilai KKM 75 . Ada 32 orang atau 88,88\% peserta didik yang memperoleh nilai tuntas, Nilai tertinggi yang dihasilkan pada siklus ini adalah 94 dari skor sempurna, yaitu 100. Nilai ratarata kelas yang didapatkan peserta didik adalah 82,86.Pada siklus II , nilai peserta didik dalam menulis puisi telah memenuhi standar yang ditetapkan oleh guru.

Hasil pengamatan guru terhadap proses belajar mengajar di kelas hari ini memperlihatkan bahwa peserta didik mulai terbiasa menulis puisi dengan metode ini. Mereka merasa senang dan tidak canggung lagi untuk mengungkapkan pikirannya, kemudian menyatukannya dengan pendapat teman sekelompoknya. Mereka terlihat sangat antusias ketika menulis puisi dengan metode ini.

Sesuai dengan hasil peningkatan skor nilai dan keaktifan peserta didik dalam proses pembelajaran dari siklus I dan siklus II yaitu dari hanya 18 peserta didik yang mendapat nilai tuntas di siklus I, dan meningkat menjadi 32 orang peserta didik yang memperoleh nilai tuntas. Menurut Suryosubroto (2005),secara kelompok, ketuntasan belajar dinyatakan telah tercapai jika sekurang-kurangnya $85 \%$ dari peserta didik dalam kelompok yang bersangkutan telah memenuhi kriteria ketuntasan secara perorangan. Ketuntasan klasikal yang diperoleh pada siklus kedua mencapai 88,88\%, Dengan demikian bahwa ketuntasan belajar yang diharapkan sudah tercapai.

Berdasarkan pencapaian yang diperoleh baik dari ketuntasan nilai hasil belajar dari evaluasi siklus I dan siklus II sudah dianggap tercapai, maka penelitian dihentikan sampai pada siklus II.Karena data yang diperoleh dipandang cukup untuk mengambil keputusan.Menurut pendapat Widoyoko (2008), Peneliti Tindakan Kelas (PTK) adalah penelitian tindakan (action research) yang dilakukan dengan tujuan memperbaiki mutu praktik pembelajaran di kelas. Penelitian yang dilaksanakan dengan melakukan proses pembelajaran melalui metode Parsipatori di kelas VII-A SMP Negeri 266 Jakarta, pada semester genap tahun ajaran 2014/2015, pada materi menulis puisi berkenaan dengan keindahan alam, terdapat perkembangan dan kemajuan yang sangat meningkat, baik dari keaktifan peserta didik maupun kegiatan guru pada tiap pertemuan pada tiap siklus, dan peningkatan rata-rata skor yang diperoleh peserta didik dalam tiap diadakan eval berikut adalah uasi dari siklus I dan siklus II.Berdasarkan hal itu maka hasil penelitian yang dilaksanakan sudah sejalan dengan tujuan PTK itu sendiri.Dengann demikian penerapan proses pembelajaran model kooperatif dengan metode Parsipatori ini dapat meningkatkan aktifitas dan prestasi belajar peserta didik kelas VII-A, SMP Negeri 266 Jakarta tahun ajaran 2014/2015 pada kompetensi Menulis puisi merkenaan dengan keindahan alam.

Hasil menunjukkan peningkatan partisipatif peserta didik dan diikuti dengan peningkatan perolehan nilai rata-rata hasil belajar di akhir siklus II, yakni 32 orang, peserta didik yang mencapai nilai KKM dan nialai tertinggi 94, sementara nilai terendah 68. Berikut adalah perbandingan frekuensi dan peresentasi nilai sikus I dan Siklus II. 
Tabel PerolehanPeningkatan Hasil Belajar Siklus I dan Siklus II

\begin{tabular}{cllll}
\hline $\begin{array}{c}\text { Rentang } \\
\text { nilai }\end{array}$ & $\begin{array}{c}\text { Siklus } \\
\text { I }\end{array}$ & $\begin{array}{c}\text { Prosentase } \\
\text { Siklus I }\end{array}$ & $\begin{array}{c}\text { Siklus } \\
\text { II }\end{array}$ & $\begin{array}{c}\text { Prosentas } \\
\text { e } \\
\text { Siklus II }\end{array}$ \\
\hline $\mathbf{6 5 - 6 9}$ & 5 & 13,88 & 1 & 2,77 \\
$\mathbf{7 0 - 7 4}$ & 13 & 36,11 & 3 & 8,33 \\
$\mathbf{7 5 - 7 9}$ & 10 & 27,77 & 4 & 11,11 \\
$\mathbf{8 0 - 8 4}$ & 6 & 16,66 & 12 & 33,33 \\
$\mathbf{8 5 - 8 9}$ & 1 & 2,77 & 10 & 27,77 \\
$\mathbf{9 0 - 9 4}$ & 1 & 2,77 & 6 & 16,66 \\
\hline
\end{tabular}

Dari tabel di atas menunjukkan bahwa ada kenaikan frekuensi pada siklus I dan II dengan demikian metode kooperatif Parsipatori dapat digunakan untuk mengajar pelajaran Bahasa Indonesia pada Kompetensi Menulis Puisi berkenaan dengan keindahan alam.

\section{Simpulan}

Berdasarkan pembahasan di atas dapat disimpulkan bahwa metode Kooperatif Partisipatori dapat meningkatkan hasil belajar menulis puisi,serta dapat meningkatkan kompetensi di Sekolah Menengah Negeri 266 Jakarta. Selain itu metode ini dapat meningkatkan aktivitas belajar dan dapat membantu siswa dalam memecahkan masalah.

\section{Ucapan Terima Kasih}

Terima kasih kepada semua pihak yang membantu penulis dalam menyelesaikan artikel hasil riset ini sehingga bisa diterbitkan di Jurnal Hortatori.

\section{Daftar Rujukan}

Akhadiah, S., dkk. Pembinaan kemampuan menulis bahasa Indonesia. Jakarta: Erlangga, 1999.

Aqib, Z. Karya tulis ilmiah bagi pengembangan profesi guru. Bandung: Yrama Widya, 2004.

Boeriswati, E. Makalah penelitian tindakan kelas. Jakarta: Universitas Negeri Jakarta, 2006. Busrodin. Pengetahuan dasar mengarang. Jakarta: Departemen Pekerjaan Umum, 1995.

Campbell, L., dkk. Metode praktis pembelajaran berbasis multiple intelligence. Depok: Intusi Press, 2004.

D, Bayli ,dkk. Mengelola kelas inklusif dengan pembelajaran yang ramah, New York: UNESCO, 2001.

De Potter, B., dkk. Quantum learning. Bandung: MLC, 2005.

Depdiknas. Bahasa dan sastra Indonesia. Jakarta: Depdiknas, 2004.

Depdiknas. Kamus Besar Bahasa Indonesia. Jakarta: Depdiknas, 2009.

Departemen Pendidikan Nasional. Kurikulum tingkat satuan pendidikan. Jakarta: Depdiknas, 2006.

Hamalik, O. Proses belajar mengajar. Bandung: Bumi Aksara, 2006.

Hayon, J. Membaca dan menulis wacana. Jakarta: Stori Grafika, 2003.

Hernowo. Quantum writing. Bandung: MLC, 2006.

Jihad, A. Evaluasi Pembelajaran. Yogyakarta : Multi Presindo, 2008.

Mikkelsen, B. Metode penelitian partisipatoris dan upaya-upaya pemberdayaan. Jakarta: Yayasan Obor Indonesia, 2001.

Ngalim, P. Psikologi Pendidikan. Bandung: Remaja Karya, 1988. 
20 Efforts to improve learning outcomes of Indonesian language through participatory method in SMP Negeri 266 Jakarta

Pidarta, M. Perencanaan pendidikan partisipatoris dengan pendekatan sistem. Jakarta: Rineka Cipta, 1990.

Pradopo. Menulis puisi. Jakarta: Remaja, 2002.

Semiawan, C. R. Memupuk bakat dan minat kreativitas sekolah menengah. Jakarta: Gramedia, 1984. 